\title{
Fungsi Ginjal Pasien Thalassemia Mayor yang Mendapatkan Kelasi Besi Oral
}

\author{
Teny Tjitra Sari, ${ }^{*}$ Aulia Fitri Swity, ${ }^{*}$ Hikari Ambara Sjakti, ${ }^{*}$ Eka Laksmi Hidayati, ${ }^{*}$ Dian Puspita Sari** \\ *Departemen Ilmu Kesehatan Anak Fakultas Kedokteran Universitas Indonesia/RS Dr. Cipto Mangunkusumo, Jakarta \\ **Departemen Ilmu Kesehatan Anak Fakultas Kedokteran Universitas Sriwijaya/RS. Moh. Hoesin, Palembang
}

Latar belakang. Peningkatan angka kelangsungan hidup pasien thalassemia menyebabkan terdeteksinya berbagai penyakit komorbid termasuk komplikasi pada ginjal. Anemia kronis, kelebihan besi, dan pemakaian kelasi besi, terutama kelasi besi oral diduga berpengaruh pada fungsi ginjal. Berbagai derajat disfungsi tubular dan abnormalitas laju filtrasi glomerulus (LFG) dideteksi dengan berbagai macam pemeriksaan.

Tujuan. Membandingkan laju filtrasi ginjal (tubulus dan glomerulus) pada pasien thalassemia yang mendapatkan kelasi besi oral. Metode. Penelitian potong lintang ini dilakukan di Pusat Thalassemia RS. Cipto Mangunkusumo Jakarta pada bulan Maret - Juli 2017. Kriteria inklusi adalah pasien thalassemia major berusia $<18$ tahun, dan telah mendapatkan kelasi oral minimal selama 1 tahun. Kriteria eksklusi adalah pasien telah memiliki penyakit atau kelainan ginjal sebelumnya dan menggunakan kelasi besi kombinasi. Pasien menjalani pemeriksaan hematologi, kreatinin serum, feritin serum, dan pengambilan urin pagi sewaktu untuk pemeriksaan kadar kalsium dan kreatinin urin sewaktu.

Hasil. Penurunan nilai LFG pada 15 pasien deferipron (DFP) 53,6\%, tetapi masih dalam batas normal, sedangkan 12 pasien deferasirox (DFX) 46,2\%. Tidak ada perbedaan bermakna antara fungsi tubular ginjal yang dinilai berdasarkan rasio kalsium kreatinin urin pada pasien thalassemia yang mendapatkan DFP dibandingkan dengan DFX. Terdapat $1(3,6 \%)$ pasien dengan hiperkalsiuria pada kelompok DFP dan 7 pasien (12,9\%) dengan hiperkalsiuria pada kelompok DFX.

Kesimpulan. Terdapat penurunan fungsi ginjal pada pasien yang mendapat kelasi besi oral, walaupun hal ini tidak bermakna. Pemeriksaan fungsi tubular maupun glomerular ginjal pasien thalassemia mayor perlu dinilai secara berkala, mengingat penggunaan kelasi besi jangka panjang dan cukup tingginya angka kejadian penurunan LFG dan hiperkalsiuria. Pemeriksaan rasio kalsium kreatinin urin maupun LFG perlu diukur pada saat pasien kontrol bersamaan dengan pemeriksaan kreatinin serum. Sari Pediatri $2018 ; 20(4): 242-8$

Kata kunci : laju filtrasi ginjal, thalassemia, kelasi besi oral

\section{Renal Function in Thalassemia Mayor Who Treat with Oral Iron Chelation}

\author{
Teny Tjitra Sari, ${ }^{*}$ Aulia Fitri Swity, ${ }^{*}$ Hikari Ambara Sjakti, ${ }^{*}$ Eka Laksmi Hidayati, ${ }^{*}$ Dian Puspita Sari**
}

Background. The increased s urvival of thalassemia patients results in possibility to detect a ny comorbidities, including renal complication. Chronic anemia, iron overload, and iron chelation therapy, especially oral iron chelation, are assumed to have impact on renal function. Different degree of tubular dysfunction and abnormality of glomerular filtration rate (GFR) can be detected by many modalities.

Objective. This study aimed to compare GFR (tubule and glomerulus) in thalassemia patients that consumed oral iron chelator in Cipto Mangunkusumo Hospital.

Methods. This study was a cross sectional study, conducted at Thalassemia Center Cipto Mangunkusumo Hospital, Indonesia during March - July 2017. Inclusion criteria were thalassemia major, aged under 18 years, and oral iron chelator had been being consumed for the last 1 year. Exclusion criteria were the presence of renal abnormalities and usage of combination chelation therapy before the study. Subjects underwent hematology, serum creatinine, serum ferritin, and morning urine test to assess calcium and creatinine level in urine.

Results. This study found decreased GFR in 15 subjects with DFP (53.6\%), but they were still in normal range, while 12 subjects with DFX (46,2\%). The difference of renal tubular function, assessed by urine calcium to creatinine ratio, between subjects with DFP and DFX was insignificant. One subject (3.6\%) on DFP group and 7 subjects (12.9\%) on DFX group had hypercalciuria.

Conclusions. Decreased renal function is observed in patient with oral iron chelation therapy, although it is insignificant. Tubular and glomerular functions should be regularly examined because iron chelation therapy must be consumed for long term and the prevalence of decreased GFR and hypercalciuria are high. Ratio of urine calcium to creatinine and GFR must be assessed at the same day as serum creatinine examination. Sari Pediatri 2018;20(4):242-8

Keyword : renal glomerular filtration rate, thalassemia, oral chelation

Alamat korespondensi: Teny Tjitra Sari. Departemen Ilmu Kesehatan Anak Fakultas Kedokteran Universitas Indonesia/RS Dr. Cipto Mangunkusumo, Jakarta. Email: t_tjitrasari@yahoo.com 
Teny Tjitra Sari dkk: Fungsi ginjal pasien thalassemia mayor yang mendapatkan kelasi besi oral

T

halassemia merupakan kelainan single gene yang paling sering ditemukan di dunia. Tahun 2018, jumlah pasien thalassemia di RS Cipto Mangunkusumo mencapai 666 pasien. Usia tertua di RS Cipto Mangunkusumo mencapai usia 50 tahun. Meningkatnya angka kelangsungan hidup pasien thalassemia menyebabkan terdeteksinya berbagai penyakit komorbid termasuk komplikasi pada ginjal. Anemia kronis, kelebihan besi, dan pemakaian kelasi besi tertentu diduga saling berkaitan terhadap manifestasi kelainan ginjal pada pasien thalassemia $\beta$. Kelainan tubular serta disfungsi glomerulus telah terjadi pada penderita thalassemia mayor, bahkan sebelum menunjukkan gejala. Derajat kerusakan ginjal dapat bervariasi mulai dari proteinuria, aminoasiduria dan peningkatan NAG urin yang menunjukkan kerusakan tubular ginjal. Hiperfiltrasi ginjal, hiperkalsiuria dan albuminuria juga seringkali ditemukan pada pasien thalassemia. Keadaan ini diduga berkaitan dengan anemia kronis dan intensitas transfusi yang tinggi.

Berbagai penelitian klinis menunjukkan berbagai derajat disfungsi tubular dan abnormalitas laju filtrasi glomerulus (LFG) adalah hal yang umum dijumpai pada pasien thalassemia $\beta .{ }^{4,5}$ Berbagai pemeriksaan dilakukan untuk mendeteksi adanya gangguan pada disfungsi dan abnormalitas laju filtrasi glomerulus. Penelitian pada model tikus percobaan yang mengalami kelebihan besi didapatkan perubahan baik pada struktur maupun fungsi glomerulus dan tubulointerstitial. Struktur glomerulus menunjukkan adanya glomerulosklerosis, sedangkan pada tubulointerstitial menunjukkan atropi tubular terutama pada bagian proksimal, dan fibrosis interstitial. ${ }^{4}$ Penelitian Economou $\mathrm{dkk}^{6}$ juga memperlihatkan adanya keterlibatan ginjal pada pasien anak dan dewasa muda thalassemia mayor yang mendapatkan kelasi besi yang ditunjukkan dengan peningkatan kadar cys C, hiperkalsiuria, peningkatan ekskresi $\beta_{2}$-mikroglobulin di urin, dan proteinuria. Kadar cys $\mathrm{C}$ serum meningkat secara signifikan sedangkan bersihan kreatinin dan LFG menunjukkan hasil yang normal. Sampai saat ini, pemeriksaan cys $C$ belum menjadi standar pelayanan.

Hiperkalsiuria dapat menunjukkan adanya kerusakan tubular ginjal yang menyebabkan gangguan absorpsi ion termasuk kalsium. Pemeriksaan ini didapatkan melalui pemeriksaan urin 24 jam. Namun demikian, pemeriksaan urin 24 jam sulit dilakukan pada anak sehingga skrining hiperkalsiuria dilakukan dengan pemeriksaan rasio kalsium kreatinin urin sewaktu. Pengukuran LFG kreatinin menggunakan rumus Counahan-Barrat tidak dapat mendeteksi penurunan fungsi ginjal pada pasien thalassemia $\beta$ mayor dengan hemokromatosis yang mendapatkan kelasi besi DFO. Pengukuran fungsi tubular dapat menggunakan beta- 2 microglobulin dan $\mathrm{N}$-acetyl- $\beta$ D-glucosaminidase. ${ }^{4}$ Penelitian Rosifah menggunakan peningkatan perbandingan kadar $\mathrm{N}$-acetyl- $\beta$-Dglucosaminidase (NAG)/kreatinin urin sebagai penanda gangguan fungsi tubulus ginjal pada thalassemia $\beta$ mayor yang mendapat kelasi besi oral. Adanya laporan kasus nefrotoksisitas akibat kelasi besi oral DFX dan DFO yang terjadi gangguan fungsi tubular hingga gagal ginjal juga menjadi pendorong untuk dilakukan penelitian ini.

Tujuan penelitian ini adalah membandingkan laju filtrasi ginjal (tubulus dan glomerulus) pada pasien thalassemia yang mendapatkan kelasi besi oral di RS Cipto Mangunkusumo.

\section{Metode}

Penelitian ini merupakan penelitian potong lintang yang dilakukan di Pusat Thalassemia RS. Cipto Mangunkusumo Jakarta, Indonesia pada bulan Maret - Juli 2017. Kriteria inklusi adalah pasien thalassemia major yang berusia $<18$ tahun, dan telah mendapatkan kelasi oral minimal selama 1 tahun. Kriteria eksklusi adalah pasien telah memiliki penyakit atau kelainan ginjal sebelumnya dan menggunakan kelasi besi kombinasi.

Penelitian dilakukan dengan cara darah vena diambil $3 \mathrm{ml}$ ke dalam tabung yang berisi larutan EDTA (ethylene diamine tetra acetic acid) untuk pemeriksaan hematologi lengkap. Sebanyak 3-5 ml darah lainnya dilakukan sentrifugasi untuk memisahkan serumnya untuk pemeriksaan kreatinin darah dan feritin. Hasil pemeriksaan kreatinin dinyatakan dalam satuan $\mathrm{mg} /$ dL. Feritin serum diperiksakan dengan metode enzyme immunoassay dan hasilnya dinyatakan dalam satuan $\mu \mathrm{g} / \mathrm{L}$. Feritin adalah kadar feritin yang diperiksa maksimal dalam jangka waktu 3 bulan sebelum dilakukan penelitian, dinyatakan dalam $\mathrm{ng} / \mathrm{mL}$. Rerata feritin adalah rata-rata kadar feritin yang diperiksa dalam 1 tahun terakhir, dinyatakan dalam ng/mL.

Pasien juga dilakukan pengambilan urin pagi sewaktu untuk pemeriksaan kadar kalsium dan kreatinin urin sewaktu, hasil dinyatakan dalam $\mathrm{mg} / \mathrm{dL}$. Laju 
filtrasi glomerulus adalah volume plasma yang dapat dibersihkan dari substansi tertentu oleh ginjal dalam suatu unit waktu, dihitung berdasarkan formula Schwartz revisi dan dinyatakan dalam $\mathrm{ml} /$ menit/1,73 $\mathrm{m}^{2}$. Laju filtrasi glomerulus dikatakan menurun jika < $90 \mathrm{ml} / \mathrm{menit} / 1,73 \mathrm{~m}^{2}$ dan dikatakan meningkat jika > $140 \mathrm{ml} / \mathrm{menit} / 1,73 \mathrm{~m}^{2}$. Rasio kalsium kreatinin urin adalah perbandingan antara kadar kalsium urin dengan kreatinin dalam urin, dinyatakan dalam $\mathrm{mg} / \mathrm{mg}$. Dalam penelitian ini dikatakan meningkat apabila nilainya $>0,29$. Hiperkalsiuria adalah ekskresi kalsium lebih dari $4 \mathrm{mg} / \mathrm{kg} / 24$ jam yang ditandai dengan peningkatan rasio kalsium kreatinin urin sewaktu. Hiperfiltrasi glomerulus didefinisikan sebagai LFG seluruh ginjal yang tinggi secara abnormal, peningkatan fraksi filtrasi, ataupun peningkatan filtrasi per nefron.

Data diolah menggunakan program SPSS 21.0. Pada perbandingan antar kelompok kelasi besi oral DFP dan DFX, nilai rasio kalsium kreatinin urin dan LFG berupa variabel numerik akan diuji dengan uji t tidak berpasangan bila sebaran data normal dan jika sebaran data tidak normal maka akan digunakan uji Mann Whitney. Selanjutnya untuk melihat hubungan antara variabel dengan LFG, kadar kreatinin serum dan rasio kalsium kreatinin urin dilakukan analisis multivariat dengan uji korelasi Pearson jika sebaran data normal dan apabila sebaran data tidak normal akan digunakan uji korelasi Spearman.

\section{Hasil}

Karakteristik subjek penelitian tertera pada Tabel 1 . Dalam kurun waktu setahun, 15 (53,6\%) pasien yang mendapatkan DFP mengalami penurunan LFG, tetapi nilainya masih dalam batas normal. Sementara pasien yang mendapatkan DFX terdapat $12(46,2 \%)$ pasien yang mengalami penurunan LFG, 2 di antaranya memiliki LFG $<90 \mathrm{ml} /$ menit $/ 1,73 \mathrm{~m}^{2}$. Terdapat 1 $(3,6 \%)$ pasien dengan hiperkalsiuria pada kelompok DFP dan 7 (12,9\%) dengan hiperkalsiuria pada kelompok DFX (Tabel 1). Tabel 2 memperlihatkan perbandingan LFG dan rasio kalsium kreatinin urin pada pasien thalassemia mayor yang mendapatkan kelasi besi oral. Semuanya tidak menunjukkan perbedaaan bermakna.

Tabel 3 memperlihatkan hubungan bivariat antara berbagai variabel dengan LFG, rasio kalsium kreatinin urin dan kreatinin serum. Berdasarkan analisis bi- variabel didapatkan LFG berkorelasi kuat dengan kreatinin serum, dan tidak berkorelasi bermakna dengan usia, durasi penyakit, lama penggunaan kelasi, dosis kelasi, hemoglobin, feritin maupun saturasi transferin. Rasio kalsium kreatinin urin memiliki korelasi lemah dengan usia, hemoglobin, dan saturasi transferin, serta berkorelasi sedang dengan rerata hemoglobin. Kadar kreatinin serum berkorelasi kuat dengan usia dan LFG, serta berkorelasi sedang dengan durasi penyakit. Namun, formula Schwartz menggunakan kadar kreatinin serum dalam menghitung LFG sehingga kami tidak melakukan analisis lebih lanjut.

Faktor yang memiliki korelasi bermakna dengan rasio kalsium kreatinin urin ini merupakan kandidat variabel untuk pemodelan analisis regresi linier berganda dengan $\mathrm{p}<0,25$. Setelah dilakukan pemodelan analisis regresi linier berganda didapatkan model terakhir dengan hasil terdapat korelasi bermakna antara rasio kalsium kreatinin urin dengan dosis kelasi besi, kadar feritin dan rerata $\mathrm{Hb}$ dalam 1 tahun (Tabel 4).

\section{Pembahasan}

Dengan meningkatnya kesadaran tentang komplikasi ginjal pada thalassemia dan berkembangnya pengetahuan tentang mekanisme cedera pada ginjal menyebabkan peningkatan monitoring fungsi ginjal, terutama yang mendapatkan kelasi besi. Hal ini menjadi penting terutama pasien risiko tinggi, yaitu pasien yang disertai diabetes, pasien gangguan ginjal sebelumnya (atau dengan LFG GFR $<60 \mathrm{~mL} / \mathrm{min} / 1,73 \mathrm{~m} 2$ and proteinuria). ${ }^{4}$ Penelitian kami mendapatkan 15 (53,6\%) pasien yang mendapatkan DFP mengalami penurunan LFG, tetapi nilainya masih dalam batas normal. Sementara pada kelompok DFX terdapat $12(46,2 \%)$ pasien yang mengalami penurunan LFG, 2 di antaranya memiliki LFG $<90 \mathrm{ml} / \mathrm{menit} / 1,73 \mathrm{~m}^{2}$. Dari beberapa penelitian jangka panjang yang memonitor efikasi maupun efek samping dari penggunaan DFP, belum pernah dilaporkan mengenai perubahan fungsi ginjal pada pasien thalassemia yang menggunakan kelasi besi tersebut. ${ }^{14-16}$ Penyebab terjadinya penurunan LFG pada subjek penelitian kami belum dapat ditentukan secara pasti. Riwayat penggunaan kelasi besi sebelumnya dapat dipertimbangan berperan dalam hal tersebut.

Pada penelitian ini juga mendapatkan $46,2 \%$ dari kelompok pasien yang mendapatkan DFX mengalami 
Teny Tjitra Sari dkk: Fungsi ginjal pasien thalassemia mayor yang mendapatkan kelasi besi oral

Tabel 1. Karakteristik subjek penelitian

\begin{tabular}{|c|c|c|}
\hline & $\begin{array}{c}\text { DFP } \\
\mathrm{n}=28\end{array}$ & $\begin{array}{c}\text { DFX } \\
\mathrm{n}=26\end{array}$ \\
\hline \multicolumn{3}{|l|}{ Jenis kelamin } \\
\hline Perempuan (\%) & $11(39)$ & $20(76,9)$ \\
\hline Laki-laki (\%) & $17(60,7)$ & $6(23,1)$ \\
\hline \multicolumn{3}{|l|}{ Usia (bulan) } \\
\hline Rerata (SB) & $145,2(50,3)$ & $115,6(46,1)$ \\
\hline \multicolumn{3}{|l|}{ Durasi penyakit (bulan) } \\
\hline Rerata (SB) & $115,7(52,3)$ & $97,7(48,4)$ \\
\hline \multicolumn{3}{|c|}{ Lama penggunaan kelasi (bulan) } \\
\hline Median (rentang) & $68,5(24-132)$ & $25(12-108)$ \\
\hline \multicolumn{3}{|c|}{ Dosis kelasi besi (mg/kg/hari) } \\
\hline Median (rentang) & $90,5(71,4-103,2)$ & $27,6(21,3-67,3)$ \\
\hline \multicolumn{3}{|c|}{ Rerata $\mathrm{Hb} 1$ tahun $(\mathrm{g} / \mathrm{dL})$} \\
\hline Rerata (SB) & $8,3(0,7)$ & $8,2(0,9)$ \\
\hline \multicolumn{3}{|c|}{ Rerata feritin 1 tahun (ng/mL) } \\
\hline Median (rentang) & $2895,4(1274,5-6777,2)$ & $3614,6(1571,2-10506,3)$ \\
\hline \multicolumn{3}{|l|}{ Hb saat ini $(\mathrm{g} / \mathrm{dL})$} \\
\hline Median (rentang) & $8,5(5,50-10)$ & $8,8(4,5-10,6)$ \\
\hline \multicolumn{3}{|l|}{ Feritin saat ini $(\mathrm{ng} / \mathrm{mL})$} \\
\hline Median (rentang) & $3504(526,7-6671)$ & $3443(1298-14400)$ \\
\hline \multicolumn{3}{|l|}{ Saturasi transferin $(\%)$} \\
\hline Median (rentang) & $94,5(30-103)$ & $73,5(18-103)$ \\
\hline LFG menurun* (\%) & $15 / 28(53,6)$ & $12 / 26(46,2)$ \\
\hline Hiperkalsiuria** $(\%)$ & $1 / 28(3,6)$ & $7 / 26(12 / 9)$ \\
\hline
\end{tabular}

* Setelah pemantauan 1 tahun, ** Rasio kalsium kreatinin urin $>0,29$

Tabel 2. Perbandingan LFG dan rasio kalsium kreatinin urin pada thalassemia mayor yang mendapat kelasi besi oral

\begin{tabular}{llll}
\hline & DFP* $^{*}$ & DFX $^{*}$ & Nilai $^{*}$ \\
\hline LFG $(\mathrm{ml} /$ menit/1,73 m $)$ & $14,1(25)$ & $128,5(25,6)$ & 0,427 \\
\hline Rasio Kalsium/Kreatinin urin & $0,25(0,14)$ & $0,33(0,21)$ & 0,109 \\
\hline
\end{tabular}

*Data dalam rerata $(\mathrm{SB})$, "Uji t tes tidak berpasangan

Tabel 3. Analisis bivariat variabel yang diduga memengaruhi fungsi ginjal

\begin{tabular}{|c|c|c|c|c|c|c|}
\hline \multirow[t]{2}{*}{ Variabel } & \multicolumn{2}{|c|}{ LFG } & \multicolumn{2}{|c|}{ Rasio kalsium kreatinin urin } & \multicolumn{2}{|c|}{ Kreatinin serum } \\
\hline & $\mathrm{r}$ & $\mathrm{P}$ & $\mathrm{r}$ & $\mathrm{p}$ & $\mathrm{r}$ & $\mathrm{p}$ \\
\hline Usia & 0,047 & 0,737 & $-0,292$ & 0,032 & 0,572 & $<0,005$ \\
\hline Durasi penyakit & 0,062 & 0,657 & $-0,021$ & 0,879 & 0,429 & 0,001 \\
\hline Lama kelasi & 0,045 & 0,749 & $-0,098$ & 0,483 & 0,297 & 0,029 \\
\hline Dosis kelasi & 0,053 & 0,706 & $-0,253$ & 0,065 & 0,164 & 0,235 \\
\hline Hemoglobin & $-0,074$ & 0,593 & 0,324 & 0,017 & $-0,164$ & 0,235 \\
\hline Feritin & 0,182 & 0,187 & $-0,263$ & 0,056 & 0,033 & 0,810 \\
\hline Saturasi transferin & 0,212 & 0,125 & $-0,316$ & 0,020 & 0,105 & 0,450 \\
\hline Rerata hemoglobin & $-0,215$ & 0,119 & 0,401 & 0,003 & $-0,025$ & 0,858 \\
\hline Rerata feritin & 0,095 & 0,496 & $-0,248$ & 0,071 & 0,105 & 0,451 \\
\hline Kreatinin serum & $-0,736$ & $<0,005$ & $-0,136$ & 0,326 & & \\
\hline LFG & & & $-0,098$ & 0,479 & $-0,736$ & $<0,005$ \\
\hline $\begin{array}{l}\text { Rasio } \\
\text { kalsium/kreatinin } \\
\text { urin }\end{array}$ & $-0,098$ & 0,479 & & & $-0,136$ & 0,326 \\
\hline
\end{tabular}


Teny Tjitra Sari dkk: Fungsi ginjal pasien thalassemia mayor yang mendapatkan kelasi besi oral

Tabel 4. Hasil analisis regresi rasio kalsium kreatinin urin

\begin{tabular}{lccccc}
\hline Variabel & Koefisien $\beta$ & SE & $\mathrm{R}$ & $\mathrm{R}^{2}$ & Nilai $\mathrm{p}$ \\
\hline Awal & & & 0,553 & 0,305 & \\
$\quad$ Usia & $-1,471$ & 0,000 & & & 0,971 \\
$\quad$ Dosis kelasi & $-0,001$ & 0,001 & & & 0,067 \\
Hemoglobin & 0,014 & 0,019 & & & 0,458 \\
$\quad$ Feritin & $-1,360$ & 0,000 & & & 0,328 \\
$\quad$ Saturasi transferin & $-0,001$ & 0,001 & & & 0,504 \\
$\quad$ Rerata hemoglobin & 0,044 & 0,030 & & & 0,157 \\
$\quad$ Rerata feritin & 1,502 & 0,000 & & & 0,934 \\
$\quad$ Konstanta & $-0,203$ & & & \\
Akhir & & & & \\
$\quad$ Dosis kelasi & $-0,001$ & 0,001 & 0,534 & & \\
$\quad$ Feritin & $-1,291$ & 0,000 & & & 0,015 \\
$\quad$ Rerata hemoglobin & 0,061 & 0,021 & & & 0,055 \\
$\quad$ Konstanta & $-0,260$ & & & \\
\hline
\end{tabular}

penurunan LFG, 2 di antaranya memiliki $L F G<90$ $\mathrm{ml} / \mathrm{menit} / 1,73 \mathrm{~m}^{2}$. Hal in senada dengan penelitian Economou $\mathrm{dkk}^{6}$ yang melibatkan 42 pasien thalassemia anak dan dewasa muda yang mendapat kelasi, mendapatkan rerata LFG $128 \pm 17,45 \mathrm{ml} /$ menit/1,73 $\mathrm{m}^{2}$ yang tidak berbeda bermakna dengan kontrol sehat, juga tidak berbeda bermakna antara kelompok yang mendapatkan DFX dibandingkan dengan DFP dan DFO. penelitian Piga $\mathrm{dkk}^{17}$ menunjukkan pemberian DFX pada pasien thalassemia mayor selama 2 tahun berkaitan dengan penurunan LFG hingga 17,7\% pada minggu ke-52 dan 17,2\% pada minggu ke-104.

Mekanisme penyebab terjadinya gangguan fungsi ginjal yang berkaitan dengan pemberian kelasi besi belum diketahui secara pasti. Beberapa hipotesis menyatakan hal tersebut berkaitan dengan pemberian kelasi besi yang berlebihan kemudian menyebabkan deplesi besi relatif dan penurunan LFG. Hal ini disebabkan oleh kerusakan fungsi mitokondrial di sel tubular, produksi adenosin dan adenosin trifosfat yang mengaktivasi umpan balik tubuloglomerular, vasokontriksi pembuluh darah glomerular dan penurunan LFG; dan juga berkaitan dengan kaskade asam arakidonat dan produksi prostaglandin yang menyebabkan perubahan hemodinamik intrarenal serta LFG.

Pada penelitian kami mendapatkan tidak terdapat perbedaan bermakna antara LFG pada pasien thalassemia yang mendapat DFP dibandingkan dengan DFX $(\mathrm{p}=0,427)$, dengan perbedaan rerata $5,5 \mathrm{ml} /$ menit/1,73 $\mathrm{m}^{2}$ (IK 95\% 8,3-19,3). Hal ini senada dengan penelitian Economou dkk ${ }^{6}$ yang menyatakan tidak terdapat perbedaan LFG pada pasien thalassemia mayor yang mendapatkan DFX dibandingkan dengan terapi kombinasi DFP dan DFO.

Hiperfiltrasi diduga merupakan keadaan yang disebabkan oleh anemia kronik, dibuktikan dengan meningkatnya kejadian peningkatan klirens kreatinin pada pasien yang tidak mendapatkan transfusi adekuat. Sedangkan penurunan klirens kreatinin diduga berkaitan dengan transfusi rutin dan supresi sumsum tulang dan rendahnya reseptor transferin serum yang disebabkan oleh anemia. ${ }^{3,5}$ Pada keadaan anemia terjadi penurunan resistensi vaskular sistemik yang mengakibatkan sirkulasi yang hiperdinamik sehingga meningkatkan aliran darah renal dan LFG. Hiperfiltrasi dapat mengakibatkan peregangan dinding kapiler dan kerusakan epitel glomerulus sehingga pada akhirnya terjadi penurunan LFG yang progresif. Apabila kondisi penumpukan besi makin berat akan terjadi kerusakan sel tubular, dan pada akhirnya mencetuskan sitokin dan growth factor interstitial sehingga menyebabkan skar dan sklerosis glomerular. ${ }^{19,20}$ Penelitian kami mendapatkan $9(32,1 \%)$ pasien pengguna DFP dan $8(30,8 \%)$ pasien pengguna DFX yang memiliki nilai LFG $>140 \mathrm{ml} / \mathrm{menit} / 1,73 \mathrm{~m}^{2}$.

Ginjal merupakan organ yang penting dalam homeostasis kalsium yang merupakan salah satu ion yang penting dalam tubuh. Kalsium yang telah difiltrasi sebagian besar akan mengalami reabsorpsi di tubulus proksimal, sementara sisanya akan direabsorpsi di ansa Henle, tubulus distal dan duktus koligens. Quinn 
Teny Tjitra Sari dkk: Fungsi ginjal pasien thalassemia mayor yang mendapatkan kelasi besi oral

$\mathrm{dkk}^{3}$ mendapatkan rasio kalsium kreatinin urin yang meningkat pada pasien thalassemia yang mendapat kelasi besi. Frekuensi dan derajat hiperkalsiuria juga berkaitan dengan intensitas transfusi yang tinggi. Pada penelitian kami secara statistik tidak terdapat perbedaan rasio kalsium kreatinin urin pasien yang mendapatkan DFP dibandingkan dengan DFX $(0,25 \pm 0,14$ dan $0,33 \pm 0,21, p=0,109)$. Namun, didapatkan 7 pasien $(12,9 \%)$ pasien yang memiliki nilai rasio kalsium kreatinin melebihi batas atas nilai normal, yaitu 6 orang pasien yang menggunakan DFX dan 1 orang pasien yang menggunakan DFP. Hal ini menunjukkan terdapatnya hiperkalsiuria pada pasien tersebut yang dapat merupakan tanda dari kerusakan tubular ginjal. Penelitian kami senada dengan Economou $\mathrm{dkk}^{6}$ yang mendeteksi adanya hiperkalsiuria pada $35,5 \%$ pasien thalassemia mayor dan kadar kalsium urin yang meningkat bermakna dibandingkan dengan kontrol $(5,3 \pm 3,54$ dan $1,8 \pm 0,91 \mathrm{mg} / \mathrm{kg} /$ hari, $\mathrm{p}<0,001)$, tetapi tidak berbeda bermakna di antara kedua kelompok kelasi besi. Demikian juga dengan penelitian Hamed $\mathrm{dkk}^{22}$ yang menyatakan adanya hiperkalsiuria pada pasien thalassemia yang bermakna dibandingkan dengan kontrol, tetapi tidak ada perbedaan bermakna antara yang mendapatkan kelasi besi dibandingkan dengan yang tidak, dengan rerata kadar kalsium urin 13,24 $\pm 4,53$ vs $12,63 \pm 5,26 \mathrm{mg} / \mathrm{dL}$.

Pada penelitian ini, usia, durasi penyakit, lama penggunaan kelasi besi, dosis kelasi besi, hemoglobin, rerata feritin maupun rasio kalsium kreatinin urin tidak berkorelasi dengan LFG. Demikian juga rasio kalsium kreatinin urin tidak dipengaruhi oleh durasi penyakit maupun lama penggunaan kelasi besi. Rasio kalsium kreatinin urin berkorelasi lemah dengan usia, hemoglobin, dan saturasi transferin, serta berkorelasi sedang dengan rerata hemoglobin.

Hal ini sesuai dengan penelitian Lai $\mathrm{dkk}^{23}$ yang mendapatkan tidak adanya hubungan bermakna antara penurunan LFG dengan usia dimulainya kelasi maupun kadar feritin serum. Meskipun demikian, kadar $\mathrm{Hb}$ yang bervariasi berkaitan dengan bertambahnya risiko terjadinya penurunan LFG sehingga menunjukkan pentingnya mempertahankan kadar $\mathrm{Hb}$ pretransfusi antara 9,5 sampai dengan 10,5 g/dL. Anemia dan hemosiderosis merupakan faktor utama yang berperan dalam terjadinya kerusakan tubular ginjal.

Quinn $\mathrm{dkk}^{3}$ dan Economou $\mathrm{dkk}^{6}$ menyatakan kadar feritin serum bukan merupakan faktor prediktor untuk menunjukkan terjadinya kerusakan baik glomerular maupun tubular ginjal. Kerusakan tubular ginjal dapat berkaitan dengan lamanya penggunaan kelasi, lamanya transfusi, dan jumlah besi dalam darah yang ditransfusikan. ${ }^{3}$

Penelitian kami juga mendapatkan kadar kreatinin serum berkorelasi kuat dengan usia dan LFG, serta berkorelasi sedang dengan lama sakit thalassemia. Kadar kreatinin serum terutama dipengaruhi oleh fungsi glomerulus dan nilainya meningkat sesuai usia. Penelitian Hamed $\mathrm{dkk}^{22}$ menemukan adanya disfungsi glomerular dan tubular pada pasien thalassemia $\beta$ yang ditandai dengan peningkatan kreatinin dan albumin serum, penurunan LFG, peningkatan asam urat dan fosfat. Kelebihan besi, anemia dan hipoksia kronis diduga merupakan faktor utama yang menyebabkan kelainan ginjal pada pasien thalassemia mayor. ${ }^{18}$ Pemeriksaan fungsi tubular maupun glomerular ginjal pasien thalassemia mayor perlu dinilai secara berkala, mengingat penggunaan kelasi besi jangka panjang dan cukup tingginya angka kejadian penurunan LFG dan hiperkalsiuria. Pemeriksaan rasio kalsium kreatinin urin maupun LFG perlu diukur pada saat pasien kontrol bersamaan dengan pemeriksaan kreatinin serum.

Sebagai kesimpulan, laju filtrasi glomerulus pasien thalassemia yang mendapat DFP tidak berbeda bermakna dibandingkan dengan pasien yang mendapat DFX. Tidak ada perbedaan bermakna antara fungsi tubular ginjal yang dinilai berdasarkan rasio kalsium kreatinin urin pada pasien thalassemia yang mendapatkan DFP dibandingkan dengan DFX.

\section{Daftar pustaka}

1. Data Pusat Thalassemia RSCM, Jakarta 2018 (unpublished data).

2. Sumboonnanonda A, Malasit P, Tanphaichitr VS, Ongajyooth S, Sunthornchart S, Pattanakitsakul S, dkk. Renal tubular function in $\beta$-thalassemia. Pediatr Nephrol 1998;12:280-3.

3. Quinn CT, Johnson VL, Kim H-Y, Trachtenberg F, Vogiatzi MG, Kwiatkowski JL, dkk. Renal dysfunction in patients with thalassaemia. Br J Haematol 2011;153:111-7.

4. Bakr A, Al-Tonbary Y, Osman G, El-Ashry R. Renal complications of $\beta$-thalassemia major in children. Am J Blood Res 2014;4:1-6

5. Mallat NS, Mallat SG, Musallam KM, Taher AT. Potential mechanisms for renal damage in $\beta$-thalassemia. J Nephrol 2013;26:821-8

6. Economou M, Printza N, Teli A, Tzimouli V, Tsatra I, 
Teny Tjitra Sari dkk: Fungsi ginjal pasien thalassemia mayor yang mendapatkan kelasi besi oral

Papachristou F, dkk. Renal dysfunction in patients with $\beta$-thalassemia major receiving iron chelation therapy either with deferoxamine and deferiprone or with deferasirox. Acta Haematol 2010;123:148-52.

7. Butani L, Kalia A. Idiopathic hypercalciuria in children - how valid are the existing diagnostic criteria? Pediatr Nephrol 2004;19:577-82.

8. Sorkhi H, Aahmadi MH. Urinary calcium to creatinin ratio in children. Indian J Pediatr 2005;72:1055-6.

9. Hendriyono FX. Laju filtrasi glomerulus penderita thalassemia mayor dengan hemokromatosis menggunakan uji bersihan kreatinin dan kadar cystatin C serum [Tesis]. Jakarta: Universitas Indonesia; 2005.

10. Rosifah D, Hilmanto D, Gurnida DA. Perbandingan kadar N-Acetyl- $\beta$-D-Glucosaminidase urin pada thalassemia $\beta$ mayor anak yang mendapat deferipron dan deferasiroks. Sari Pediatri 2014;16:167-72.

11. Grange S, Bertrand DM, Guerrot D, Eas F, Godin M. Acute renal failure and Fanconi syndrome due to deferasirox. Nephrol Dial Transplant 2010;25:2376-8.

12. Volti SL, Maccarone C, Volti GL, Romeo MA. Acute renal failure following deferoxamine overdose. Pediatr Nephrol 2003;18:1078-9.

13. Helal I, Fick-Brosnahan GM, Reed-Gitomer B, Schrier RW. Glomerular hyperfiltration: definitions, mechanisms and clinical implications. Nat Rev Nephrol 2012;8:293-300.

14. Cohen AR, Galanello R, Piga A, Sanctis VD, Tricta F. Safety and effectiveness of long-term therapy with the oral iron chelator deferiprone. Blood 2003;102:1583-7.

15. Viprakasit V, Nuchprayoon I, Chuansumrit A, Torcharus K, Pongtanakul B, Laothamatas J, dkk. Deferiprone (GPO-LONEVR ) monotherapy reduces iron overload in transfusiondependent thalassemias: 1-year results from a multicenter prospective, single arm, open label, dose escalating phase III pediatric study (GPO-L-ONE; A001) from Thailand. Am J Hematol 2013;88:251-60.

16. Olivieri NF, Brittenham GM, McLaren C, Templeton DM, Cameron RG, McClelland RA, dkk. Long term safety and effectiveness of iron chelation therapy with deferiprone for thalassemia major. N Engl J Med 1998;339:417-23.

17. Piga A, Fracchia S, Lai ME, Cappellini MD, Hirschberg R, Habr D, dkk. Deferasirox effect on renal haemodynamic parameters in patients with transfusion-dependent $\beta$ thalassemia. Br J Haematol 2015;168:882-90.

18. Musallam KM, Taher AT. Mechanisms of renal disease in $\beta$-thalassemia. J Am Soc Nephrol 2012;23:1299-302.

19. Fucharoen $S$, Winichagoon P. Haemoglobinopathies in Southeast Asia. Indian J Med Res 2011;134:498-506.

20. Adly AAM, Toaima DN, Mohamed NR, Seoud KMAE. Subclinical renal abnormalities in young thalassemia major and intermedia patients and its relation to chelation therapy. The Egypt J Med Hum Gen 2014;15:369-77.

21. Sreedharan R, Avner ED. Tubular Function. Dalam: Kliegman RM, Stanton BF, StGemeIII JW, Schor NF, penyunting. Nelson Textbook of Pediatric. Edisi ke-20. Philadelphia: Elsevier; 2016.h.2528.

22. Hamed EA, ElMelegy NT. Renal functions in pediatric patients with $\beta$-thalassemia major: relation to chelation therapy: original prospective study. Ital J Pediatr 2010;36:110 .

23. Lai ME, Spiga A, Vacquer S, Carta MP, Corrias C, Ponticelli C. Renal function in patients with $\beta$-thalassaemia major: a longterm follow-up study. Nephrol Dial Transplant 2012;27:354751.

24. Ghasemi A, Azimzadeh I, Afghan M, Momenan AA, Bagheripour F. Pediatric reference values for serum creatinine and estimated glomerular filtration rate in Iranians: Tehran Lipid and Glucose Study. Arch Iran Med 2015;18:753-9. 